\title{
LEARNING THE GENETICS CONCEPTS THROUGH PROJECT ACTIVITIES USING Drosophila melanogaster: A QUALITATIVE DESCRIPTIVE STUDY
}

\author{
Ahmad Fauzi ${ }^{1 *}$ and Shefa Dwijayanti Ramadani ${ }^{2}$ \\ ${ }^{1}$ Departement of Biology Education, University of Muhammadiyah Malang, Indonesia \\ ${ }^{2}$ Departement of Biology Education, Islamic University of Madura, Pamekasan-Indonesia \\ *corresponding e-mail: ahmad_fauzi@umm.ac.id
}

\begin{abstract}
Genetics is one of difficult subject for many undergraduate students majoring biology. Authentic-based research is one of learning activity believed could overcome the situation. One of Genetics course that facilitating the students to conduct authentic-based research is Genetics course in Faculty of Mathematics and Natural Science, State University of Malang. The aim of this study was to describe the project research activities in Genetics course, especially the authentic-based research that utilize Drosophila melanogaster. The present study is qualitative descriptive with the object of this study is project activities in Genetics course. In this institution, the Genetics course is divided into Genetics I (taken by fourth semester students) and Genetics II (taken by fourth semester students). Data collection was conducted from 2014 until 2017 using open ended interviews and observation. An analytical strategy from Miles \& Huberman was used to analyze the data. D. melanogaster was used as model organism in several Genetics projects. The genetics project was conducted from first until sixteenth week. In the project activities, the students get some flies strains, observe its phenotypes, design their research project, collect the data, analyze the data, prepare the report, ant present their project result. In this activities, students could practice to be a real researcher. Based on interviews with some students and observations during the presentation of the project reports, it can be seen that through this learning activities the students achieved better understanding about many genetics concepts. Moreover, several students have an opportunity to present their research results in International Conference events.
\end{abstract}

Keywords: Authentic-based researchs, drosophila, genetics course, genetics project, genetics learning

(C) 2017 Department of Biology Education, FTTE, University of Muhammadiyah Malang, Indonesia

\section{INTRODUCTION}

Genetics is the branch of biology studying all of thing related to the heredity and variation (Klug et al., 2012; Snustad \& Simmons, 2012; Tamarin, 2004). It has a central position in entire biological study (Huether \& McCance, 2012; Sandelowski, 2000). Besides occupying a central position, genetics is also said to be a fundamental branch of biology (Knippels et al., 2005; McElhinny et al., 2014). The understanding of genetics concepts is essential in studying various organisms, from human to microbe (Huether \& McCance, 2012). Moreover, in the current era, genetics has an important role in health issues and public policy (Bowling et al., 2008).

However, genetics is not an easy topic in biology (Bahar et al, 1999; Knippels et al., 2005). Many students facing difficulties when they learn genetics (Abraham et al., 2014;
McElhinny et al., 2014; Mills Shaw et al., 2008). As a matter of fact, Genetics becomes a hard subject for student, although for those who are undergraduate student majoring biology (Smith \& Knight, 2012).

One of reasons why genetics is a difficult subject in undergraduate school because most of the concepts studied in genetics are abstract (Chattopadhyay, 2005; Infante-malachias et al., 2010). Moreover, the material contents in genetics are very complex (Knippels, 2002; Knippels et al., 2005). Therefore, many students struggle to understand many genetics concepts, such as the relation between gene and chromosome, the Mendelian genetics, and the genes interaction (Infante-malachias et al., 2010; Smith \& Knight, 2012). Furthermore, many students also facing difficulties to interconnect the genetics concepts in macro, micro, and sub-micro level (Knippels et al., 2005). 
Several reports try to look for the alternative genetics learning design that can overcome the problem in genetics subject (Knippels, 2002; Knippels et al., 2005; Pukkila, 2004). There are some criteria for designing genetics course that can overcome the abstractness and the complexity of genetics concepts. One of the criteria is the learning should present a familiar phenomenon for students (Knippels et al., 2005). In another sense, learning must be able to present the phenomenon that was orginally abstract into classroom.

One of learning activity that can bring a phenomenon into classroom is through practical activity. Related to the practical activities, a good practical is a practical that capable facilitating students doing activity like real researcher (Fauzi, 2017; Fauzi et al., 2016). The meaning of the practicum like real researcher is the practical activities that facilitating students to find the research idea, to design the research, until to report and to communicate the findings independently (Fauzi et al., 2016; Srisawasdi, 2012). Through such activities, students are possible to learn by doing, learning activities are increasingly emphasized in many learning institutions (Merkel, 2003).

The Genetics courses at Faculty of Mathematics and Natural Science, State University of Malang (Genetics I and Genetics II) is one of genetics learning that facilitates student to conduct a research. The research activitiy in the course known as "Genetics Project". The Genetic Project I will be performed by all of Genetics I students, whereas Genetics Project II will be performed by all of Genetics II students. In this research activity, several model organisms are used by students (Fauzi, 2017; Fauzi et al., 2016).

One of model organisms used in the genetics project Faculty of Mathematics and Natural Science, State University of Malang is Drosophila melanogaster (Fauzi, 2017). D. melanogaster are commonly known as fruit fly (Snustad \& Simmons, 2012; Tamarin, 2004). The organism is belong to the order Diptera (Class Insects) (Roberts, 2006). The imago stage of the fly has a pair of wings and three pairs of legs. When D. melanogaster reaching the stag, the size of the body ranging from three until five mm (Chyb \& Gompel, 2013).

The exitence of genetics project is just one of the characteristics in genetics courses at Faculty of Mathematics and Natural Science, State University of Malang. The other characteristics is the approach used in this course. The approach of this course is content approach, it does not like the other genetics course in the other universities (Fauzi, 2017; Fauzi et al., 2016). Besides the exitence of genetics project and the approach, the other characteristic is the learning model used in this course. Genetics course Faculty of Mathematics and Natural Science, State University of Malang is consistently use Reading Questioning and Answering model, a learning model that developed by Prof. A. D. Corebima, one of lecture in Genetics Course in that institution (Corebima \& Bahri, 2011; Fauzi, 2017). The exitence of these characteristics attrached has attracted several researchers to research this course (Fauzi, 2017; Fauzi et al., 2016; Khairil, 2009). Even though there have been researchs that studying the Genetics courses in Faculty of Mathematics and Natural Science, State University of Malang, but, until now, there is no single research focusing on the utilization of D. melanogaster in detail.

Research that inform the description of $D$. melanogaster utilization in Genetics courses at Faculty of Mathematics and Natural Science, State University of Malang needs to exist as an alternative information about how to teach Genetics concepts in colleges. The reason, based on observation that have been carried out until 2017, there are still many Genetics courses at several universities in Indonesia that have not involved any practical activities at all. Based on the interviews conducted on 20 alumni from those universities, it was known that they were difficulties in understanding many Genetics concepts. On the other hand, Faculty of Mathematics and Natural Science, State University of Malang alumni understand those Genetics concepts. Therefore, the study that studying the project activities in Faculty of Mathematics and Natural Science, State University of Malang needs to be conducted because it can provide information regarding both the process and the benefits of implementing project activities in Genetics course.

\section{METHOD}

A qualitative descriptive design was used in this study with the aim to describe the research project using D. melanogaster in Genetics courses at Faculty of Mathematics and Natural Science, State University of Malang deeply. 
Therefore, the subject of this study was project activities in Genetics course at this institution. The limitations of this study are only focused to provide an overview of genetic project activities in that course. Therefore, in this study, the matters relating to how effective the application of project activities on the improvement of students' learning outcomes or students' thinking skills were not examined.

Same as the other qualitative descriptive study, data collection in this study using minimally to moderately structured open ended interviews. The interviews were conducted on lectures, project assistants, and students. The Genetic lecturers are Prof. Dr. Aloysius Duran Corebima, M. Pd.; Prof. Dr. Siti Zubaidah, M. Pd.; and Prof. Dr. (agr). Moh. Amin, S. Pd., M. Si.Besides interviews, data were also collected using observation. The data were collected during 2014 until 2017.

The data were analyzed by using an analytical strategy from Miles \& Huberman, which consists of six steps (Miles \& Huberman, 1994). The first step was data coding. In this step, all notes collected from observation and interviews were re-read and tagged with with a word or a phrase that could represent the important information contained in each note. The second step was writing and reflecting the data deeply. All raw data that has been collected and labeled should be pointed out and converted into information that can be understood by the reader. During the rewrite process, reflections were also made on those notes. The various ideas, reactions, or insights that arose during this reflection process were recorded.

The third step was data sorting based on the information content and pattern. Based on information that are produced in second step, then, all notes are sorted and sequenced. From this step, all notes that has been collected were aranged into a sequential depiction that more ordered. Then, the next step is looking for similarities and differences for further analysis.

Then, The fifth step was generalizing the results. In this step, the various data were clustered into several groups. Thus, a large amount of data that have been obtained could be reduced into the smaller number of analytic units. Then, all of anlytic units were linked to each other into a framework. This framework was used as the basis of general concepts' formulation.
Finaly, the sixth step is connecting generalization results with references and theories. At this step, each general concepts generated from fifth step was linked with an existing concept or the results from previous study. Through this step, all the points that were written in fifth step will be more meaningful.

\section{RESULTS AND DISCUSSION}

Genetic project is a research that must be conducted by both Genetics I students and Genetics II students. The series of research activities were conducted from the begining until the end of semester. D. melanogaster was used for model organism in several project in Genetics I. The model organism was used to reveal several concepts. Those several concepts related to Mendelian inheritance, from Mendel I Law, Mendel II Law, sex-linked, crossing over, epistasis, sex ratio, lethal gene, until nondisjunction. In Genetics II, D. melanogaster was also used in several genetics projects. Some theme of genetics project in Genetics II that utilize D. melanogaster, among others: 1) the influence of environmental factors on the phenotype of the organisms; and 2) the influence of chemical, biological, and physical factors on various genetic phenomena

There were no recipe or cooking book used by students when they conducted their research. Consultations with the project assistants optimally is the factor that play as key role for research success. In Genetics I, students were guided to design a research procedures that correspond with their researchs topics. Those research topics come from their project assistants. After collecting the data, students were guided to reveal that phenomenon actually happened in their D. melanogaster crossbreeds. On the other hand, in Genetics II, students were more independetly designing their research. Project assistants just decided their research theme, while the research topics, the treatments, the researchs designs, and D. melanogaster strains that will be used would be decided by students themselves.

Based on the interviews with lecturers and project assistants, D. melanogaster was chosen as the model organisms in almost of genetics projects in Faculty of Mathematics and Natural Science, State University of Malang due to some reasons. Those reasons were: (1) easy on culturing the organism; (2) several genetics concepts could be studied from this organisms; 
(3) D. melanogaster has many mutant strains; (4) the life cycle of the organisms is fast; (5) it do not need llarge space on culturing the organisms; and (6) it is cheaper compare to the other organisms. Those reasons are also the reasons for many biologist used $D$. melanogaster as their model organisms in their studies (Chyb \& Gompel, 2013; Fauzi \& Corebima, 2015; Fauzi, Corebima, \& Zubaidah, 2016; Jennings, 2011; Roberts, 2006).

D. melanogaster actually become the primadona in many biological field studies, especially in genetics studies (Kohler, 1994). Moreover, many genetics textbooks provide much informations related to the utilization of D. melanogaster as model organisms in genetics field study (Klug et al., 2012; Snustad \& Simmons, 2012; Tamarin, 2004).

Several characteristics of $D$. melanogaster have been mentioned to bring the organisms as media that can facilitate students studying several genetics concepts. In this regards, several previous researchs have also been verifying the ease of using $D$. melanogaster as a media for studying many genetics concepts (Fauzi \& Corebima, 2016, 2016b, 2016a). Moreover, several technical advantegous make D. melanogaster become more and more popular in many educational institutions in many countries. As it has sholrt life cycle, the D. melanogaster can be used as research subjects until many generations in one academic years (Flannery, 1997; Jeszenszky, 1997; Sofer \& Tompkins, 1994).

In Genetics Laboratory of Faculty of Mathematics and Natural Science, State University of Malang, D. melanogaster was cultured in $200 \mathrm{ml}$ glass bottles with the height is $9 \mathrm{~cm}$ and the diameter is $7 \mathrm{~cm}$. The glass bottles filled with $25-35 \mathrm{ml}$ media and the top of the bottles is closed by cork (Figure 1.).

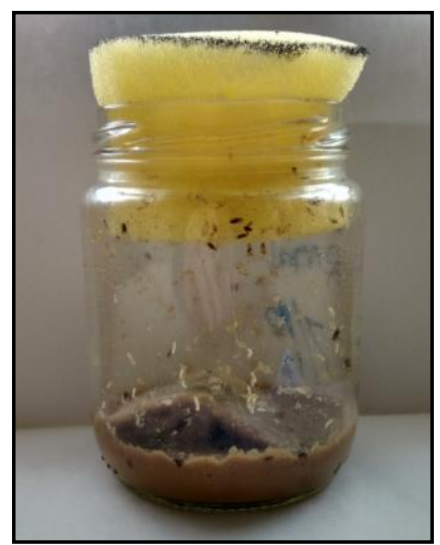

Figure 1. A culture bottle of D. melanogaster
Actually, the natural food of $D$. melanogaster is rotten fruits (Chyb \& Gompel, 2013). But, in laboratory, D. melanogaster are commonly feed by using banana pulp. Actually, there are many various food compositions that can be used in culturing $D$. melanogaster, from simple compostion with the main menu is banana, until complex composition that did not contain banana at all (Jennings, 2011; Kohler, 1994).

In Genetics Laboratory of Faculty of Mathematics and Natural Science, State University of Malang, the food composition of D. melanogaster is a mixture of 700 grams of bananas (rajamala variety), 200 grams of fermented cassava/tapai, 100 grams of palm sugar, and adequate water. The bananas were mix with tapai by using blender and palm sugar was boiled until it became liquid. Then the mixture of bananas and tapai were mixed with liquid palm sugar. After that, the mixture were boiled as long as an hour (water was added sufficiently during boiling the mixture). After that, the liquid food or known as flies cultured medium was poured into culture tglass as much as $25-35 \mathrm{ml}$ and the top of the bottle was closed by using cork. After the cultured-media was cooling down, the media were added with 3-5 grains of yeasts. The flies cultured-media with this composition has been used by several researchers in their studies (Fauzi \& Corebima, 2015; Fauzi et al., 2016)

There are many $D$. melanogaster strains that can be found in Genetics Laboratory Faculty of Mathematics and Natural Science, State University of Malang. The flies cultured were kept in two culture cases (Figure 2.).

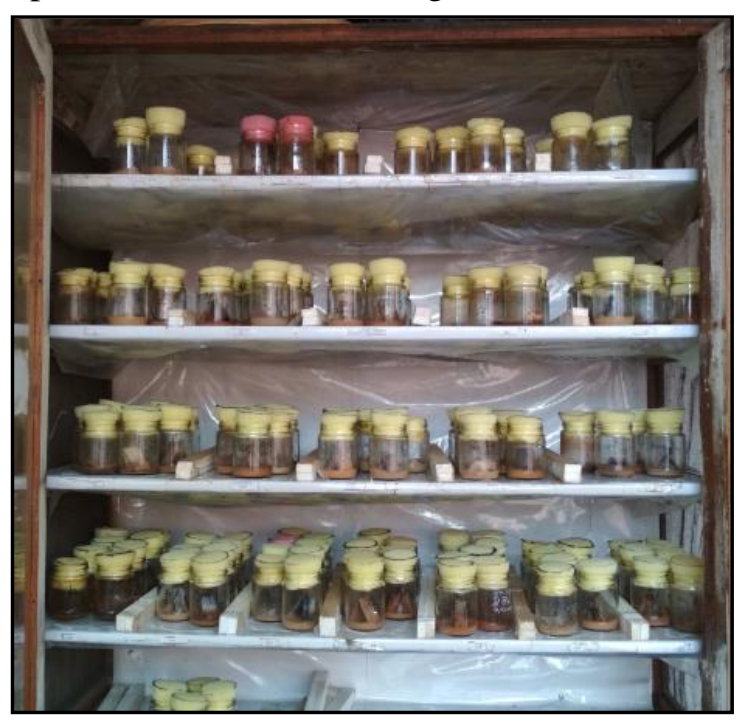

Figure 2. One of culture case in Genetics Laboratory, UM 
The total D. melanogaster strains possessed by Genetics Laboratory Faculty of Mathematics and Natural Science, State University of Malang were twenty until thirty strains (sometimes, the amount of strains are fluctuated). In the Laboratory, there were no cooler or heater machine, so the flies cultured grow in normal room temperature in Malang City that always fluctuated. Those temperatures are still toleranted by $D$. melanogaster (Economos \& Lints, 1986).

In Genetics I, each class was divided into 16 genetics project groups. Each group has different research topic and several group got D. melanogaster strains that correspond with their research topic. In Genetics I, the strains in each group were decided by project assistants, not students themselves. Groups that got Mendel I Law, epistasis, and lethal gene projects acquired strains that could be crossed in the monohybrid system, Mendel II Law in dihybrid system, whereas sex linked and nondisjuntion projects acquired gonosome mutants. The determination of strains in each phenomenon was in line with several previous researchs studying the potency of $D$. melanogaster as learning media (Fauzi \& Corebima, 2016, 2016a, 2016b).

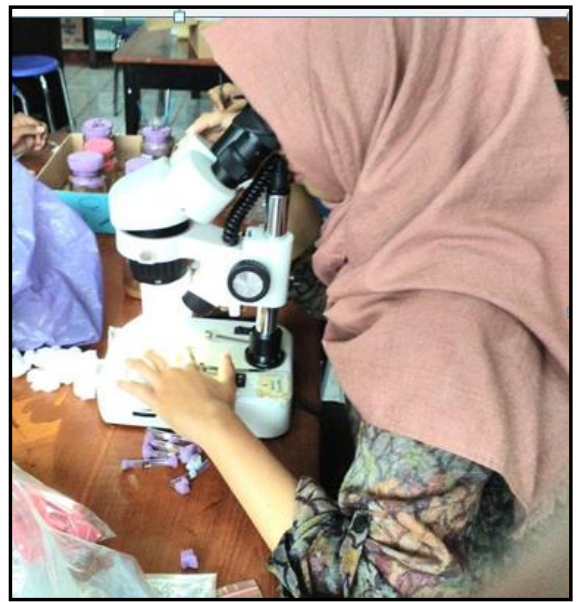

Figure 3. One of the students was observing $D$. melanogaster phenotypes

The distribution of D. melanogaster to each group were conducted in the second or third week. After that, students observed the phenotypes of their flies stock using a stereo microscope (Figure 3.). The mutant strains used by students were $w, m a l, w^{a}, b, c l, d p, v g, b c l$, $b d p, b v g, e, b a r^{3}, e y m, t x, P m, b w^{a}$, and ecl. Some mutants have mutations in genes controlling eye pigmentation, some mutants in gene controlling body pigmentation, and the others in the genes controlling wings formation (Chyb \& Gompel, 2013). So, the phenotypes that were observed just limited in three aspects, that were the color of eyes, the color of body, and the form of wings.

Students should also look for the differences between male and female phenotype. $D$. melanogaster has sexual dimorphism, the females body is larger than males and the posterior segment of the male's abdomen is dark (Chyb \& Gompel, 2013). Students should find out those differences.

After observed the phenotype, students should draw their observations and provide an explanation of their pictures in their research journal book (Figure 4.). The book contains all of activities during the project research. The book has A4 size and each page is divided into four columns. Through the journal book, students tried to use research log book, an essential component in research conducted by real researchers (Lebrun, 2007).

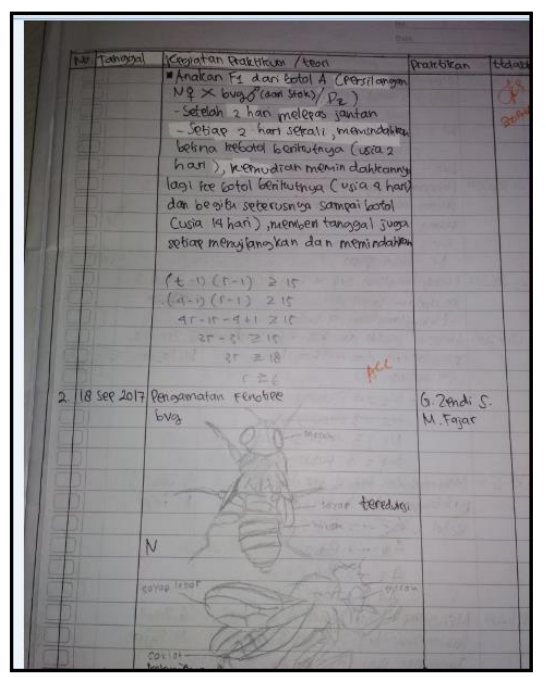

Figure 4. The picture of D. melanogaster in a student journal book

After observed the phenotypes, students consulted with their project assistant. In the first consultation, students were teached to rejuvenate the flies, to isolate the pupae, and to crosshybrid the flies. Flies rejuvenation is a multiplication of flies by moving several pairs of flies from old cultured glasses to new cultured glasses. Pupae isolation is the isolation of mature pupae by isolating dark pupae from cultured glasses to small tubes (Figure 5.). The imagos that emerge from pupae isolations were 
used for crosshybrid steps. Why? Because the crosshybridization need a pair of flies that never copulate, so the data from hybridization is not biased.

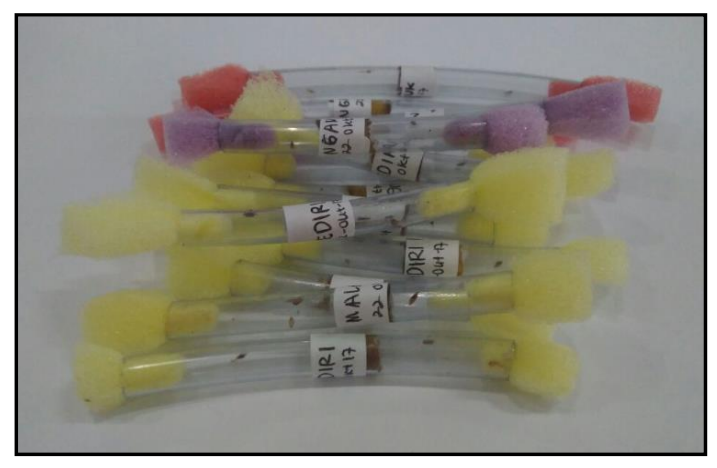

Figure 5. The dark pupaes isolated in small tubes

Afterward, students should design their research procedure. The project assistants just guided them to keep their research design in line with the Genetics course design. Afterthat, students should write their procedure in their journal book. Then, their procedure was shown to their project assistant. If the project assistant agrees with their procedure, students were allowed to begin their project research. Students should managed their schedules to cook a media, to rejuvenate the cultures, to isolate the pupaes, and to crosshybrid their flies. These activities tried their assiduity and responbility, some of the scientific attitudes that all scientists must possess (Rao, 2004). Figure 6. shown several activities conducted by students during project acitivities.
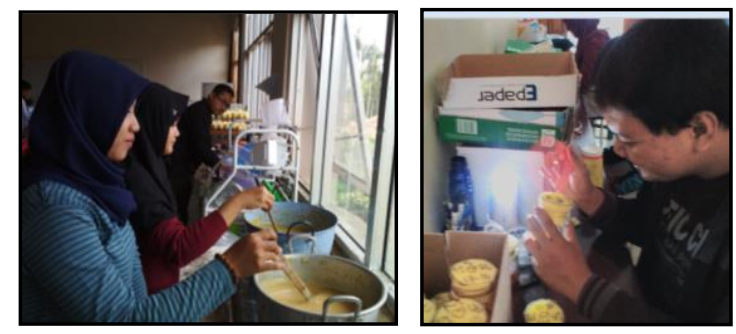

Figure 6. Two students were cooking the cultured media (left) and a student was isolating the mature pupae

In each crossbreed or in each treatment, students must decide how much replication they should meet. In determining the number of replications, students use the formula that has been used by real researcher as well, that is $(r-$ $1)(t-1)<15$, notes: $r$ is the number of replication, whereas $\mathrm{n}$ is the number of treatment. In each replication, students got hundreds of offspring because $D$. melanogaster is an organism that can produce hundreds of offspring after fertilization. Then, students must analyze the data and decide the phenomena that occur in their research. Afterthat, students also conducted the final two steps in the scientific method, those are writing a report and communicating their findings (Reiff et al., 2002).

The project research report prepared by the students was very different with practical reports in the other courses. In Genetics project, students must arranged their report according to the thesis format which has six chapters (UM, 2010). When they arranged their report, students also consulted with their project assistant, just like the thesis guidance among students with their promoters.

Afterthat, all of project groups should present their report in front of their class. The presentation activities were held at "project presentation's weeks" (thirteenth to sixteenth). Each group tried to communicate their findings orally, a skill that must be possessed by the researcher (Fauzi et al., 2016; Veit \& Gould, 2010). The other project groups listened to the presentation and then they discussed with the presenter about the findings, similar to the scientific conference forums. During the activity, the project assistants observed the presentation and discussion activities. Afterthat, they reviewed the genetics concepts associated with a research project that has been conducted by the students.

In Genetics II, students were more independent during designing their research. In procedural consultation activities, project assistant should guide students to find new creative research idea. Therefore, their research was expected to have a novelty. Novelty is newness quality that must be owned by a research (Vaishnavi \& Kuechler, 2008). Because students design their own research, students also decided strains in their own research themselves. Regardless of the flexibility of students in designing research, generally, genetics projects in Genetics II were the same as Genetics I.

To monitor research activities, everyday, each group should write their activities in their journal book, just as real researcher write their activities in their log book (Lebrun, 2007). Afterthat, they should show their work and their journal book to the project assistants (Figure 7.). Beside of that, the project researchs were monitored by project assistants through 
progress activities. In the progress activities, project assistants recorded the research progress of each group. The progress activities were conducted twice time in each semester.

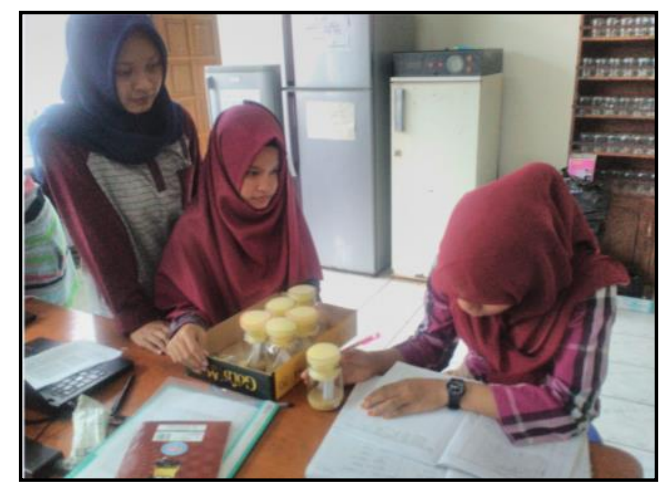

Figure 7. The projects assistants was checking the journal book of genetics students

Based on the genetics project activities presented in this report, it is clear that the genetics courses at Faculty of Mathematics and Natural Science, State University of Malang facilitate students to become actual researchers. Students learn by imitating what scientists do in discovering new science (Pukkila, 2004; Reiff et al., 2002; Veit \& Gould, 2010). Such learning activities will provide new and important experiences for students (McGee \& Keller, 2007).

In the genetics courses at Faculty of Mathematics and Natural Science, State University of Malang, students were guided to conduct authentic-based research because there were no cookbook or recipe book in research activities (Brownell et al., 2012; Fauzi et al., 2016; Srisawasdi, 2012). Research-based learning is actually the standard model recommended in higher education (Balster et al., 2010). Moreover, students' understanding of genetics concepts is improving (Hassard, 2011). This condition could be observed during the project presentation's weeks. When students presented their project results, they were able to explain the genetic concepts that underlie their project. In addition, after they presented their project results, they were also able to answer the questions from their friends and from the project assistants. The observation results is in line with the results of in-depth interviews conducted in this present study. From the interviews, it was revealed, many students have not been confused with various genetics concepts, such as Mendelian genetics and the relationship between genes, alleles, chromosomes, and traits.

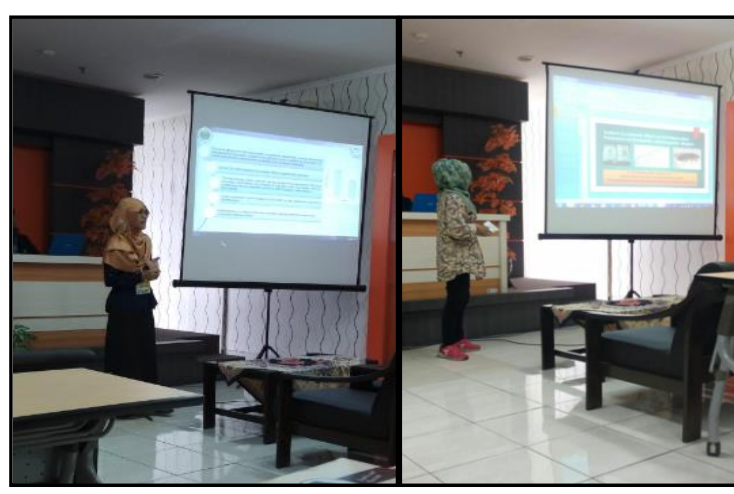

Figure 8. Anggun Risma (Left) and Eka Pratama (Right) were presenting their project genetics finding in The 8 ICGT 2017

Indeed, by guiding students to design the research with novelty, students will be given the opportunity to publish or present their findings on scientific forums. The examples are the genetics projects conducted by Anggun Risma Atika and Eka Pratama Putri, two Genetics II students in 2016. Anggun designed a research studying the effect of monosodium glutamate (MSG) on the offspring number of $D$. melanogaster. The novelty of this research is the kind of the effect that observed. Anggun observed the long-term effects of $D$. melanogaster feeding MSG in several generations, unlike previous researchs that only observed the short-term effect in just one generation.

On the other hand, Eka Pratama designed a research studying the nondisjunction event in autosomes of males flies affected by sodium cyclamate administration. Previously, many references stating that the incidence of nondisjunction occurs only in females and is only easily observed on the $\mathrm{X}$ chromosome. However, Eka Pratama reveals that the statement is incorrect. Both of Anggun and Eka Pratama have presented their findings in The 8th International Proceeding on Green Technology (ICGT) 2017 (Figure 8.).

\section{CONCLUSION}

In Genetics courses at Faculty of Mathematics and Natural Science, State University of Malang, there were project activities conducted by all students. Through those activities, all students learn the genetics concepts as well as learn to be a real 
researchers. They conducted authentic-based researchs. D. melanogaster was chosen as one of the model organisms in genetics project activities due to some technical advantages and some biological reasons.

The project activities were carried out for one semester. In the first week, each class was divided into 16 groups. In the second to third week, each group gets flies strains and observes its phenotypes. After that, they designed their project procedures and conducted their project. During the project activities, students collected data, then the data were analyzed and reported it in project report. Finally, at thirteenth to sixteenth week, they presented their project report. After conducting the research project, the understanding of genetics concepts in students increases. Moreover, some students have the opportunity to present their findings in international conference.

\section{SUGGESTION}

Genetics is one of the difficult subjects in college because of the abstract and the complexity of the concepts. By using researchbased learning, Genetics Faculty of Mathematics and Natural Science, State University of Malang could overcome the situation. Therefore, it is recommended for the other universities to apply genetics course based research in their institutions, especially by using D. melanogaster as model organism.

\section{REFERENCES}

Abraham, J. K., Perez, K. E., \& Price, R. M. (2014). The dominance concept inventory: A tool for assessing undergraduate student alternative conceptions about dominance in mendelian and population genetics. $C B E$ Life Sciences Education, 13(2), 349-358. https://doi.org/10.1187/cbe.13-08-0160

Bahar, M., Johnstone, A. H., \& Hansell, M. H. (1999). Revisiting learning difficulties in biology. Journal of Biological Education, 33(2), 84-86. https://doi.org/10.1080/002 19266.1999.9655648

Balster, N., Christine, P., Rediske, R., \& Janet, B. (2010). Entering Research: A Course That Creates Community and Structure for Beginning Undergraduate Researchers in the STEM Disciplines. Life Sciences Education, 9, 108-118. https://doi.org/10.1187/cbe.09$10-0073$
Bowling, B. V., Acra, E. E., Wang, L., Myers, M. F., Dean, G. E., Markle, G. C., Huether, C. A. (2008). Development and evaluation of a genetics literacy assessment instrument for undergraduates. Genetics, 178(1), 15-22. doi.org/10.1534/genetics.107.079533

Brownell, S. E., Kloser, M. J., Fukami, T., \& Shavelson, R. (2012). College Science Teaching ecent publications, in- cluding. Journal of College Science Teaching, 41(4), $18-27$.

Chattopadhyay, A. (2005). Understanding of genetic information in higher secondary students in northeast India and the implications for genetics education. Cell Biology Education, 4(1), 97-104. https://doi.org/10.1187/cbe.04-06-0042

Chyb, S., \& Gompel, N. (2013). Atlas of drosophila morphology: wild-type and classical mutants. London: Academic Press.

Corebima, A. D., \& Bahri, A. (2011). Reading, questioning, and answering (RQA): a new learning strategy to enhance student metacognitive skill and concept gaining. In International Symposium at Nanyang Technology University, Singapore.

Economos, A. C., \& Lints, F. A. (1986). Developmental temperature and life span in Drosophila melanogaster. I. Constant developmental temperature: evidence for physiological adaptation in a wide temperature range. Gerontology, 32(1), 1827. Retrieved from http://www.ncbi.nlm.nih. gov/pubmed/3081405

Fauzi, A. (2017). Analisis Filogeni Tarsius tarsier Form Buton dengan Beberapa Spesies Tarsius dari Sulawesi Tengah, Sumatera-Kalimantan, dan Filipina Atas Dasar Gen MT-CO2 sebagai Bahan Pengembangan Buku Panduan Penelitian Mata Kuliah Genetika II Di Universitas Negeri Mal. Universitas Negeri Malang.

Fauzi, A., \& Corebima, A. D. (2015). The Effect of EMF Radiation Emitted by Mobile Phone to Insect Population using Drosophila melanogaster as a Model Organism. In Trisilowati (Ed.), Proceeding of The 6th International Conference on Global Resource Conservation (pp. 16-20). Malang: Universitas Brawijaya.

Fauzi, A., \& Corebima, A. D. (2016). Fenomena Gagal Berpisah, Epistasis, dan Nisbah Kelamin pada Drosophila melanogaster. In Seminar Nasional Biologi 2016 (pp. 283-288). Surabaya: Universitas 
Negeri Surabaya.

Fauzi, A., \& Corebima, A. D. (2016a). Pemanfataan Drosophila melanogaster sebagai Organisme Model dalam Mempelajari Hukum Pewarisan Mendel. In Seminar Nasional Biologi 2016 (pp. 372377). Surabaya: Universitas Negeri Surabaya.

Fauzi, A., \& Corebima, A. D. (2016b). Pemanfataan Drosophila melanogaster sebagai Organisme Model dalam Mengungkap Berbagai Fenomena Penyimpangan Rasio Mendel. In Seminar Nasional Biologi 2016 (pp. 278-282). Surabaya: Universitas Negeri Surabaya.

Fauzi, A., Corebima, A. D., \& Zubaidah, S. (2016). The Fluctuation of Adult Filial Number and Eclosion Time of Drosophila melanogaster that Exposed by Mobile Phone in Multiple Generations (pp. 124-128). Malang: Universitas Brawijaya.

Fauzi, A., Corebima, A. D., \& Zubaidah, S. (2016). The Utilization of Ferns as a Model Organism for Studying Natural Polyploidization Concept in Genetics Course. In International Conference on Education (pp. 51-58). Malang: Universitas Negeri Malang.

Flannery, M. C. (1997). Models in Biology. The American Biology Teacher, 59(4), 244-248.

Hassard, J. (2011). Science as inquiry: active learning, project-based, web-assisted, and active assessment strategies to enhance student learning (2nd ed.). Culver City: Good Year Books.

Huether, S. E., \& McCance, K. L. (2012). Understanding pathophysiology (5th ed.). Maryland Heights: Mosby - Elsevier.

Infante-malachias, M. E., Queiroz, I., Padilha, D. M., Artes, E. De, Humanidades, C., \& Paulo, U. D. S. (2010). Comprehension of basic genetic concepts by brazilian undergraduate students. Revista Electrónica de Enseñanza de Las Ciencias, 9(3), 657668.

Jennings, B. H. (2011). Drosophila-a versatile model in biology \& medicine. Materials Today, 14(5), 190-195. https://doi.org/10. 1016/S1369-7021(11) 70113-4

Jeszenszky, A. W. (1997). Managing the Fruit Experiment. The American Biology Teacher, 59(5), 292-294.

Khairil. (2009). Potensi Model Perkuliahan Genetika di Jurusan Biologi FMIPA UM dalam Memberdayakan Kemampuan
Metakognisi, Kerja Ilmiah, dan Hasil Belajar Kognitif Mahasiswa. Universitas Negeri Malang.

Klug, W. S., Cummings, M. R., Spencer, C. A., \& Palladino, M. A. (2012). Concepts of Genetics (10th ed.). San Francisco: Benjamin Cummings.

Knippels, M.-C. P. J. (2002). Coping with the Abstract and Complex Nature of Genetics in Biology Education: The yo-yo learning and teaching strategy. Utrecht: CD- $\beta$ Press.

Knippels, M.-C. P. J., Arend, J. W., \& Boersma, K. T. (2005). Journal of Biological Education Design criteria for learning and teaching genetics. Journal of Biological Education, 393(393), 108112.doi.org/10.1080/00219266.2005.965597 6

Kohler, R. E. (1994). Lords of the fly: Drosophila genetics and the experimental life. University of Chicago Press.

Lebrun, J.-L. (2007). Scientific Writing: A Reader and Writer's Guide. Materials Today (Vol. 10). Singapore: World Scientific. doi.org/10.1016/S1369-7021 (07) 70134-7

McElhinny, T. L., Dougherty, M. J., Bowling, B. V., \& Libarkin, J. C. (2014). The Status of Genetics Curriculum in Higher Education in the United States: Goals and Assessment. Science and Education, 23(2), 445-464. https://doi. org/10.1007/s11191-012-9566-1

McGee, R., \& Keller, J. L. (2007). Identifying Future Scientists: Predicting Persistence into Research Training. CBE Life Sciences Education, 6, 316-331. https://doi.org/ 10.1187/cbe.07

Merkel, C. A. (2003). Undergraduate research at the research universities. Wiley Periodicals, Inc, 3(93), 39-54. https://doi. org/10.1002/tl.87

Miles, M. B., \& Huberman, A. M. (1994). Qualitative data analysis: an expanded sourcebook. Thousand Oaks: Sage Publications.

Mills Shaw, K. R., Van Horne, K., Zhang, H., \& Boughman, J. (2008). Essay contest reveals misconceptions of high school students in genetics content. Genetics, 178(3), 1157-1168. https://doi.org/10.1534/ genetics.107.084194

Pukkila, P. J. (2004). Introducing student inquiry in large introductory genetics classes. Genetics, 166(1), 11-18. https://doi.org/10.1534/genetics.166.1.11 
Rao, D. B. (2004). Scientific attitude, scientific aptitude and achievement. New Delhi: Discovery Pub. House.

Reiff, R., Harwood, W. S., \& Phillipson, T. (2002). A scientific method based upon research scientists $\hat{a} €^{\mathrm{TM}}$ conceptions of scientific inquiry. Proceedings of the Annual International Conference of the Association for the Education of Teachers in Science, 25. Retrieved from http://files.eric.ed.gov/ fulltext/ED465618.pdf

Roberts, D. B. (2006). Drosophila melanogaster: the model organism. Applicata, 121(1823), 93-103. doi.org/ 10.1111/j.1570-8703.2006.00474.x

Sandelowski, M. (2000). Focus on Research Methods: Whatever Happened to Qulitative Description? Research in Nursing \& Health, 23, 334-340. https://doi.org/10.1002/1098$240 x(2000 \quad 08) 23: 4<334::$ aid-nur9>3.0.co;2$\mathrm{g}$

Smith, M. K., \& Knight, J. K. (2012). Using the Genetics Concept Assessment to document persistent conceptual difficulties in undergraduate genetics courses. Genetics,
191(1), 21-32. https://doi.org/10.1534/ genetics.111.137810

Snustad, D. P., \& Simmons, M. J. (2012). Genetics. New Jersey: Wiley.

Sofer, W., \& Tompkins, L. (1994). Drosophila genetics in the classroom. Genetics, 136(1), 417-422.

Srisawasdi, N. (2012). Introducing Students to Authentic Inquiry Investigation Using an Artificial Olfactory System. In Issues and Challenges in Science Education Research (pp. 93-106). doi.org/10.1007/ 978-94-0073980-2_7

Tamarin, R. H. (2004). Principles of genetics. New York: McGraw-Hill.

UM. (2010). Pedoman Penulisan Karya Ilmiah (5th ed.). Malang: UM Press.

Vaishnavi, V., \& Kuechler, W. (2008). Design science research methods and patterns: innovating information and communication technology. Boca Raton: Auerbach Publications.

Veit, R., \& Gould, C. (2010). Writing, reading, and research. Boston: Cengage Learning. 